\title{
Thematic Exploration of TPK's Antagonistic Perception in his Play Fulfilment
}

\section{OPEN ACCESS}

Manuscript ID:

ENG-2020-08042948

Volume: 8

Issue: 4

Month: September

Year: 2020

P-ISSN: 2320-2645

E-ISSN: 2582-3531

Received: 18.06.2020

Accepted: 25.07.2020

Published: 01.09.2020

Citation:

Kulkarni, Prafull D.

"Thematic Exploration of TPK's Antagonistic Perception in His Play Fulfilment." Shanlax International Journal of English, vol. 8, no. 4, 2020, pp. 12-15.

DOI:

https://doi.org/10.34293/ english.v8i4.2948

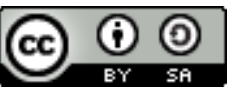

This work is licensed under a Creative Commons Attribution-ShareAlike 4.0 International License

\author{
Prafull D Kulkarni \\ Department of English, Sharadchandra College Naigaon - Nanded, Maharashtra, India \\ (D) https://orcid.org/0000-0001-7499-9118
}

\begin{abstract}
T.P. Kailasam's play, Fulfilment, is a fascinating account of the confrontation from the Mahabharata's Drona Parva between a vindicated and virtuous mortal, Eklavya, and a scheming divine, Krishna. T.P. Kailasam fictionalizes the Mahabharata myth of Ekalavya's death in the hands of Krishna and weaves it into a powerful play of deceit and treachery in which the protagonist Eklavya tragically falls victim to the antagonist Krishna's cunning act of treachery. The god, rather than protecting a virtuous human, has been shown as the one destroying him. This is entirely a new image of Krishna that T.P. Kailasam brings forward through this play, Fulfilment. The present paper aims to explore this tale of the divine antagonism from a fresh perspective.
\end{abstract}

Keywords: T.P. Kailasam, Fulfilment, Indian english drama, Mahabharata myth, Ekalavya, Krishna, Drona and The epic battle

\section{Overview}

Indian epics play a vital role in the cultural and social make-up of the Indians and their day-to-day behavior.

- Along with the Vedas, the Puranas, the Upanishads, and the Brahmanas, the Ramayana and the Mahabharata have become scriptures in the conscience of Hindu religious beliefs.

- These epics exercise a strong influence on the psyche of common men of the country. Almost every major festival, every cultural occasion, everyday social function, and sometimes, local taboos, is directed by the ethics and morals influenced by these epics.

- It is, therefore, obvious that Indian litterateurs over the years have drawn irresistibly to these epics as a treasure trove of ideas, themes, and characters for their creative outpouring.

- In these epics, Indian dramatists find tremendous wisdom of common men and a fascinating mirror of contemporary life right from the glory days of Kalidasa, Bhavabhuti and Visakhadutta to the enlightening days of Rabindranath Tagore, Sri Aurobindo, T.P. Kailasam, and to our very own era of post-modern theatre ideology dominated by Girish Karnad, Asif Currimbhoy, Badal Sircar, Uma Parameshwaran, etc.

- All these authors draw their raw material either from the Ramayana or from the Mahabharata to enlighten the modern theatre audience towards certain beliefs, towards some ethics and evils of their day to day life.

- This paper, however, deals with the Indian English dramatist, T.P. Kailasam (1884-1946), and his epic perceptions of "divinity" and "antagonism" as conceived by him in his creative urge towards modernity. 
Thanjavur Paramasiva Kailasam (TPK in short), was a prominent Indian dramatist of International stature. He was a bilingual writer of Kannada and English plays in the thirties of the twentieth century. Amongst his contemporaries, however, he had a distinct sense of literary perceptions.

- TPK was a student of geology at a British University and stayed quite a while in England in his adolescent days.

- He brought from the West new things to the indigenous theatre.

- He was very much familiar with Indian theatre traditions. His mastery over the dramatic art was exemplary.

- Because of his carefree attitude and bohemian way of living, he didn't even bother to put his words on paper, revise his writings or to think seriously of the publication of his plays. He was, as K. V. Subbanna points out, "a Bohemian. His unconventional and carefree mannerisms have become myths" (Subbanna).

- Most of his works were later published by his friends and theatre wards.

\section{TPK's Uniqueness}

- The dramatist was obsessed with the Mahabharata so much so that four of his five English plays are entirely based on the characters from this epic.

- TPK penned five complete and thirteen unfinished plays in English. All these plays are based entirely either on the mythical tales of Ramayana or the Mahabharata.

His full-length English plays are:

- The Burden (1933),

- Fulfillment (1933),

- The Purpose (1944),

- The Curse or Karna (1946), and

- Keechaka (1949).

The list of TPK's published plays highlights his fascination towards the Indian culture and the strong influence of the epics, especially the Mahabharata on the dramatist's creative urge. The Burden is based on Bharata's plight after Rama's exile from the epic Ramayana, and the other four peeps into the morals of the Mahabharata in an entirely new light. What is unique, in TPK's case, however, is that he turns the general perceptions of the renowned godly characters from the Mahabharata upside down and presents them as antagonists in Fulfilment, The Purpose, The Curse or Karna, and Keechaka. He authoritatively took some dramatic liberties in such characterization of the vastly popular Mahabharata demigods such as Eklavya, Karna, Keechaka, Bhima, Krishna, Arjuna, etc. The present paper explores this perception of the dramatist in the delineation of Lord Krishna in his play, Fulfilment.

\section{Introduction}

T.P. Kailasam's play, Fulfilment (1933), is a fascinating account of the confrontation from the Mahabharata's Drona Parva between a vindicated and virtuous mortal, Eklavya, and a scheming divine, Krishna. Mahabharata myth about the character of Eklavya tells us that Eklavya learned archery by the spiritual teachings of Dronacharya through his clay statue and later mastered the art despite the loss of his right thumb. But what happens next to this mythical character? Why doesn't he feature in the grand scheme of the epic in the following episodes again? We do not have credible versions of his further role in the Mahabharata tales involving Eklavya. Vyasa also doesn't expand such a noble character later the way he did with Karna in this grand epic. However, he vaguely mentions that Eklavya died in the hands of Krishna. And there are many other tales of this death myth with unconfirmed facts also that add to the confusion in the way of properly understanding the character and his final destiny in the epic.

This fact is to be taken into consideration while reading Kailasam's Fulfilment. TPK fictionalizes one of these myths surrounding Ekalavya's death and weaves it into a powerful play of deceit and treachery in which the protagonist Eklavya tragically falls victim to the antagonist Krishna's shrewd scheme of eliminating Arjuna's adversaries. The present paper aims to explore this tale of the divine antagonism from a thematic perspective.

\section{Exposition}

The plot of the play begins at the time when the two rival factions of Kauravas and Pandavas were in the process of gathering and marshaling their war resources before the great Kurukshetra battle. Eklavya is in the Kaurava camp, partly to aid his 
spiritual Guru, Drona, and partly to avenge his archrival, Arjuna, for the mortification he earlier had during the archery learning process.

Lord Krishna knows the great potential of Eklavya as a warrior and for his skills of archery. $\mathrm{He}$ is also aware of the consequences of the master archer's siding with the Kauravas in the upcoming battle. Therefore, in the play, he tries to dissuade Eklavya from joining the Duryodhana army. But the loyal warrior stubbornly refuses to accept Arjuna's company even after Krishna's multiple coaxing. Eklavya has a deep reverence for his tutor, Dronacharya. On the other hand, he hates Arjuna. In Kailasam's play, Ekalavya voices these reasons for siding with the Kauravas to the mediating Krishna in the following words:

'Nothing will stop me ... why with Partha's bow trained against my beloved Gurujee, my place is in the very van of the fray ... Partha, the snake that has set out to sting the very one that taught it to sting, does not know that Gurujee's other pupil is alive. But he soon will! With my shafts will I put out the eyes that irreverently aim arrows at Gurujee! I will slither the arms that raise a bow against Gurujee! (in a final burst of frenzied fury) Stop me! Nothing will stop me!' (Kailasam, 1964: 57).

Thus, even after many attempts of persuasion, Krishna fails to break the hardcore loyalty of Eklavya for the Kauravas. He knows that Karna and Eklavya on the Kaurava side, the odds heavily favored Duryodhana's army. Therefore, Krishna conspires to nullify the Eklavya effect either by hook or by crook, just like a cunning and scheming mortal does in our day-to-day life. He again visits Eklavya as a war mediator and engages him in a long debate over the topic of good and evil, courage and cowardice, and stealthily stabs the unsuspecting, gullible mortal in the back. He also kills Ekalavya's mother afterward so that she should not mourn the death of her only son. Kailasam's one-act play, Fulfilment, dramatizes this fictionalized Mahabharata episode by turning the divine figure of Krishna into an ordinary mortal in a negative shade.

In popular perception, Krishna is divine. He is revered as one of the gods by the Hindus all over. That's why the act of killing of an innocent and helpless man treacherously by the Lord in the play is "shrouded in divine mystery" (Joshi, 1984: 137). It cannot be justified in a worldly sense of strict social and legal codes and human morals. Mythologically and philosophically, it could be a genuine act of the Lord for Dharma to protect the wronged Pandavas. Still, in the layman's perception, it is a cold-blooded murder to fulfill one's selfish designs. S. Krishna Bhatta says, "Krishna's character in the play seems to be debased selfish" (Bhatta, 1977: 89). Throughout the play, Kailasam elevates the noble virtues of Eklavya above that of Krishna as the protagonist and judiciously transforms the divine image of Krishna into a murderous antagonist. The thunderous shout of Krishna before killing Ekalavya's mother (and the dramatist's stage direction associated with it), endorses this villainy of the divine:

Krishna: His poor old mother! Mother? (his face suddenly takes on a grotesquely humorous expression, but bursts into an unearthly guffaw of laughter sounding less of a human than of a hyena).

HA! HA!! HA!!! MOTHER! BROTHER!! SISTER!!!... HA! HA!! HA!!! BALABHADRA! SUBHADRA!! SUYODHANA!! PARTHA!! HA! HA!! (Kailasam 71-72).

\section{Conclusion}

This is entirely a new image of Krishna that TPK brings forward through this play. The god, rather than protecting a virtuous and noble human, has been shown instead as the one destroying him. The roots of such a characterization by Kailasam perhaps originated in the following verse of the Mahabharata in which Lord Krishna, during the battle preparations of Pandavas, says to Arjuna:

Jaraasandhaha Chaydi - raajo mahatma

Mahaabaahuhu Eklavya nishaadaha

Ekyekasaha twaddhitaartham hataaha Maaiva.

(Drona Parva) (Joshi 136).

(Translation: In your interest, I have killed the great Jarasandha, Shisupala - the King of Chedi, the great tribesman Ekalavya, one by one.)

Here, we find Kailasam dealing with the complicated debate between what is good for humanity and what is not. The rules are framed by the divine philosophical system already. Vedic 
perception is that one has to just look for these rules in his true self and understand God's dictates accordingly. In the Kailasam's play, Ekalavya realizes them after getting stabbed by Krishna. Before dying, he begs Krishna to eliminate his mother also to save her from the pangs of her son's death. And Krishna, in his new role as an antagonist, fulfills his wish accordingly.

The act of god in killing these innocents also has a divine meaning. It is interspersed all through the epic. Therefore, R. N. Sarkar points out:

The story of death, the ultimate end of all life, symbolizes a sort of divine family planning. The whole world is the Creator's family, which he has planned with both life and death, one set against the other. Death is no sin when it comes as a relief and not as a shock of life; the whole myth (of Death) seems to convey this idea. (Sarkar: 9596).

The untimely death of Ekalavya in the play could be viewed in this light. However, the injustice of the Lord presented on the stage in such a violent manner would shock the modern audience who doesn't understand or accept such a philosophical doctrine of the Vedas and Puranas wholeheartedly. The playwright, therefore, takes some dramatic liberty in delineating the known mythical characters and models them in a fresh perspective.

Kailasam's world of the Pre-Independence era, or for that matter, the world of today is full of treasons, treachery, and injustice. By presenting this Mahabharata myth in such an unusual manner, the playwright's intention perhaps is to bring to light the contemporary scenario of social and political chaos.
In the dramatist's perception, even gods resort to vile designs like men do and enforce justice over the virtuous ones uncharacteristically and unacceptably. Perhaps, the dramatist wishes to convey a message through Fulfilment that the man must fight himself against injustices rather than anticipating the supernatural power of God for his protection.

\section{References}

Bhagavad Gita Jashi Ahe Tashi, Bhakti vedanta Book Trust, 1984.

Bhatta, S. Krishna. "Kailasam's English Plays." Perspectives on Indian Drama in English, edited by Naik M.K, and S. Mokashi-Punekar, Oxford University Press, 1977.

Joshi, R.G. Myth in Indian Drama, B.R. Publishing Corporation, 1994.

Kailasam, T.P. Little Lays and Plays, B.S. Ramarao, 1964.

Kulkarni, Prafull D. Critical Essays - Plays of T.P.Kailasam, Lulu Press, 2010.

Kulkarni, Prafull D. Indian English Drama - The Epics Revisited, Lulu Press, 2010.

Naik, M.K. A History of Indian English Literature, Sahitya Akademi Publications, 2006.

Pandey, Sudhakar. Studies in Contemporary Indian Drama, Prestige, 1990.

Sarkar, R.N. An Episodic Interpretation of the Mahabharata, Atlantic Publishers, 2000.

Subbanna, K.V. "Modern Kannada Drama and Theatre." Mumbai Theatre Guide, http:// www.mumbaitheatreguide.com/dramas/ features/mkdt.asp.

\section{Author Details}

Dr. Prafull D. Kulkarni, Department of English, Sharadchandra College Naigaon - Nanded, Maharashtra, India, Email ID:drpdk70@gmail.com, 